\title{
Using the elastic properties of zircon-garnet host-inclusion pairs for thermobarometry of the ultrahigh-pressure Dora-Maira whiteschists: problems and perspectives
}

\author{
Nicola Campomenosi ${ }^{1}$ D $\cdot$ Marco Scambelluri ${ }^{1} \cdot$ Ross J. Angel $^{2} \cdot$ Joerg Hermann $^{3} \cdot$ Mattia L. Mazzucchelli $^{4,5}$. \\ Boriana Mihailova $^{6}$. Francesca Piccoli ${ }^{3}$. Matteo Alvaro ${ }^{5}$
}

Received: 28 December 2020 / Accepted: 5 April 2021 / Published online: 22 April 2021

(c) The Author(s) 2021

\begin{abstract}
The ultrahigh-pressure (UHP) whiteschists of the Brossasco-Isasca unit (Dora-Maira Massif, Western Alps) provide a natural laboratory in which to compare results from classical pressure $(\mathrm{P})$-temperature $(\mathrm{T})$ determinations through thermodynamic modelling with the emerging field of elastic thermobarometry. Phase equilibria and chemical composition of three garnet megablasts coupled with $\mathrm{Zr}$-in-rutile thermometry of inclusions constrain garnet growth within a narrow $P-T$ range at 3-3.5 $\mathrm{GPa}$ and $675-720^{\circ} \mathrm{C}$. On the other hand, the zircon-in-garnet host-inclusion system combined with Zr-in-rutile thermometry would suggest inclusion entrapment conditions below $1.5 \mathrm{GPa}$ and $650{ }^{\circ} \mathrm{C}$ that are inconsistent with the thermodynamic modelling and the occurrence of coesite as inclusion in the garnet rims. The observed distribution of inclusion pressures cannot be explained by either zircon metamictization, or by the presence of fluids in the inclusions. Comparison of the measured inclusion strains with numerical simulations shows that post-entrapment plastic relaxation of garnet from metamorphic peak conditions down to $0.5 \mathrm{GPa}$ and $600-650{ }^{\circ} \mathrm{C}$, on the retrograde path, best explains the measured inclusion pressures and their disagreement with the results of phase equilibria modelling. This study suggests that the zircon-garnet couple is more reliable at relatively low temperatures $\left(<600^{\circ} \mathrm{C}\right)$, where entrapment conditions are well preserved but chemical equilibration might be sluggish. On the other hand, thermodynamic modelling appears to be better suited for higher temperatures where rock-scale equilibrium can be achieved more easily but the local plasticity of the host-inclusion system might prevent the preservation of the signal of peak metamorphic conditions in the stress state of inclusions. Currently, we cannot define a precise threshold temperature for resetting of inclusion pressures. However, the application of both chemical and elastic thermobarometry allows a more detailed interpretation of metamorphic $P-T$ paths.
\end{abstract}

Keywords Dora-Maira Massif · Elastic thermobarometry $\cdot$ Pseudosections $\cdot$ Residual strain $\cdot$ Plastic relaxation

Communicated by Othmar Müntener.

Nicola Campomenosi

nicola.campomenosi@edu.unige.it

1 Department of Earth Science, Environment and Life, University of Genova, Corso Europa 26, 16132 Genova, Italy

2 IGG-CNR, Via G. Gradenigo 6, 35131 Padova, Italy

3 Institute of Geological Sciences, University of Bern, Baltzerstrasse 1+3, CH-3012 Bern, Switzerland

4 Mainz Institute of Multiscale Modeling and Institute of Geosciences, Johannes-Gutenberg University of Mainz, J. J. Becher-Weg 21, 55128 Mainz, Germany

5 Department of Earth and Environmental Sciences, University of Pavia, Via A. Ferrata 1, 27100 Pavia, Italy

6 Department of Earth Sciences, University of Hamburg, Grindelallee 48, 20146 Hamburg, Germany

\section{Introduction}

Mineral inclusions provide valuable information on the history of metamorphic rocks and their pressure and temperature $(P-T)$ paths since they can preserve direct evidence of extreme conditions experienced by a rock, such as ultrahigh-pressure (UHP) metamorphism. The pioneering contribution by Chopin (1984) documented coesite inclusions within garnet from the whiteschists of the Brossasco-Isasca unit (Dora-Maira Massif, Western Alps). After his discovery, this terrain has become a world-renowned setting for UHP metamorphism (e.g., Schertl et al. 1991; Chopin et al. 1991; Henry et al. 1993; Compagnoni and Hirajima 2001; Hermann 2003; Ferrando et al. 2009; Gauthiez-Putallaz et al. 2016; Groppo et al. 
2019). Considerable efforts have been made to constrain the exact $P-T$ conditions attained during metamorphism of the Brossasco-Isasca unit. The first pressure estimates of $P>2.8 \mathrm{GPa}$ by Chopin (1984), suggested a depth of mineral formation corresponding to at least $90 \mathrm{~km}$. Determining the mechanisms by which such rocks are then able to be exhumed to the Earth's surface are still a challenge for the scientific community (e.g., Malusà et al. 2015; Schenker et al. 2015).

In the last decade, interest in mineral inclusions has risen due to the refinement of the elastic thermobarometry method: an alternative approach for obtaining metamorphic $P-T$ estimates based on the elastic properties of host-inclusion mineral couples (e.g., Rosenfeld and Chase 1961; van der Molen and van Roermund 1986; Nasdala et al. 2003; Enami et al. 2007; Kohn 2014; Murri et al. 2018; Zhong et al. 2019; Alvaro et al. 2020; Gilio et al. 2020a). Mineral inclusions at room conditions commonly retain pressures (the so-called residual pressure, $P_{\text {inc }}$ ) that deviate from the external pressure because of their contrast in the elastic properties with the surrounding host. Rosenfeld and Chase (1961) were the first to suggest exploiting such residual pressures to constrain the conditions of inclusion entrapment. Since then, many studies have improved the thermo-mechanical models allowing us to achieve more accurate thermo-barometric estimates (e.g., Zhang 1998; Angel et al. 2015). The added value of elastic thermobarometry is related to (i) its independence on chemical equilibrium and (ii) its possible application to rocks lacking mineral assemblages that are sensitive to $P-T$ changes. Moreover, further developments of this method can provide quantitative information on paleostress conditions during metamorphism by exploiting the intrinsic anisotropy of the host-inclusion system (e.g., Alvaro et al. 2020).

In this work, a detailed comparison of the results of classical and elastic thermobarometric methods has been carried out on garnet-bearing whiteschists from the UHP BrossascoIsasca unit in the Dora-Maira Massif. We applied thermodynamic modelling and $\mathrm{Zr}$-in-rutile inclusion geothermometry to constrain formation of three garnet megablasts and, consequently, the conditions of inclusion entrapment. Phase equilibria estimates and the zircon-in-garnet elastic thermobarometry indicate significantly different conditions for inclusion entrapment. In the first case, we obtained $P-T$ conditions of 3-3.5 GPa and $675-720{ }^{\circ} \mathrm{C}$ while in the second case below $1.5 \mathrm{GPa}$ and $600-650{ }^{\circ} \mathrm{C}$. Several hypotheses to explain this discrepancy, including the presence of fluids, local non-hydrostatic stress during entrapment and plastic relaxation of the host-inclusion system, are evaluated and discussed. In particular, we show how the comparison between the measured strain states of our zircon inclusions and those predicted by numerical simulations for the same system can shed light on this issue.

\section{Geological background}

The Dora-Maira Massif is a pile of slices of Variscan continental crust involved in Alpine subduction and subsequent exhumation (e.g., Compagnoni et al. 1995). The Brossasco-Isasca coesite-bearing unit is estimated to be about $10 \times 4 \times 1 \mathrm{~km}$ in size (e.g., Compagnoni and Rolfo 2003) and is tectonically sandwiched between the lower-pressure San Chiaffredo, Rocca Solei and Pinerolo units (Fig. 1) that, according to current $P-T$ estimates, experienced comparable peak conditions at $2-2.4 \mathrm{GPa}$ and $500-520{ }^{\circ} \mathrm{C}$ (Groppo et al. 2019). The BrossacoIsasca UHP unit itself consists of two main sub-units, the Monometamorphic and the Polymetamorphic Complexes, derived from Alpine reworking of late Variscan granitoids (now orthogneiss) and of Variscan amphibolite-facies basement (now metapelite, eclogite, marble), respectively (Compagnoni et al. 1995). Our study focuses on solid inclusions within three garnet megablasts from the whiteschists of the Monometamorphic Complex.

Following the initial work of Chopin (1984), mineral equilibria studies supported by experimental work constrained the peak conditions to between 3.2-3.7 GPa and 720-800 ${ }^{\circ} \mathrm{C}$ (Schertl et al. 1991; Sharp et al. 1993; Simon

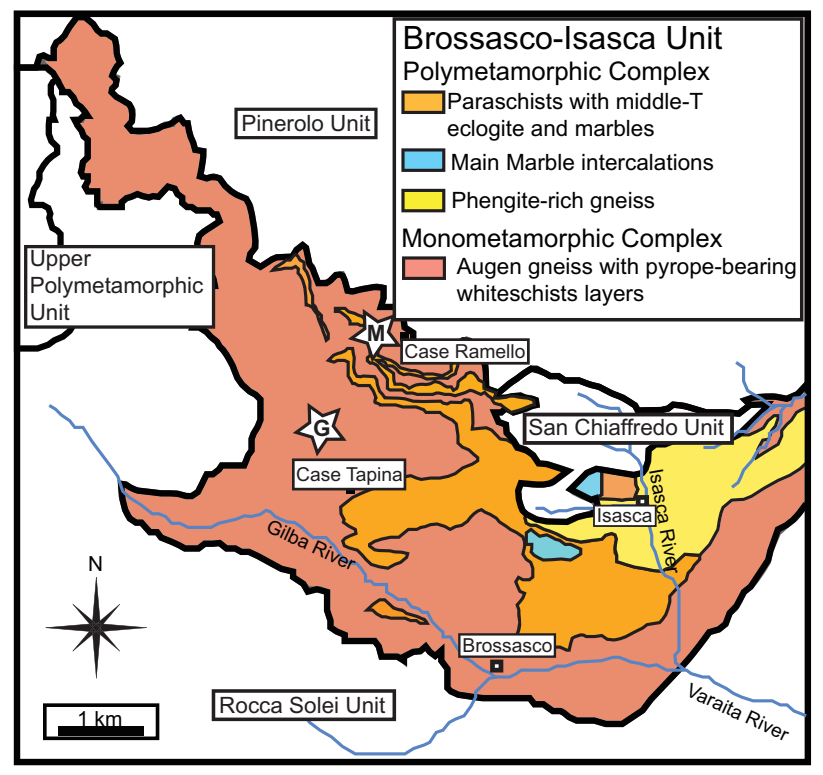

Fig. 1 Schematic geological map of the Brossasco-Isasca UHP unit (southern part of the Dora-Maira Massif). The two stars indicate the location of the two main outcrops of whiteschists. G stands for the "Gilba" locality while M stands for the "Martiniana" locality (after Castelli et al. 2007) 
et al. 1997; Rubatto and Hermann 2001; Coggon and Holland 2002; Osborne et al. 2019), with a maximum values at about 4.3 GPa and $730{ }^{\circ} \mathrm{C}$ (Hermann 2003).

Tilton et al. $(1989,1991)$ first defined the age of Alpine metamorphism of the Brossasco-Isasca unit at 34-38 Ma by $\mathrm{Sm} / \mathrm{Nd}$ dating on pyrope mineral separates. Later, Gebauer et al. (1997) using SHRIMP method on zircon crystals confirmed an age of UHP metamorphism at $35 \mathrm{Ma}$ and obtained by zircon fission track ages of $29.9 \pm 1.4 \mathrm{Ma}$. By combining, $P-T$ estimates with in situ U-Pb titanite and zircon fission track dating Rubatto and Hermann (2001) also defined three different stages at $3.5 \mathrm{GPa}, 720{ }^{\circ} \mathrm{C}$ at $35.1 \pm 0.9 \mathrm{Ma}$, $0.8-1 \mathrm{GPa}$ and $600{ }^{\circ} \mathrm{C}$ at $32.9 \pm 0.9 \mathrm{Ma}, 0.4-0.5 \mathrm{GPa}$ and $600-620^{\circ} \mathrm{C}$ at $31.8 \pm 0.6 \mathrm{Ma}$.

\section{Sample description}

The Brossasco-Isasca garnet-bearing whiteschists crop out in two main localities: (1) close to Case Ramello and Case Parigi in the Martiniana valley and (2) close to Case Tapina in the Gilba valley (Fig. 1). These rocks form lenses within the country orthogneiss of the Monometamorphic complex (e.g., Compagnoni et al. 1995) and consist mainly of quartz (former coesite), white mica, kyanite, talc and garnet; garnet crystals range in size from a few millimeters to almost $20 \mathrm{~cm}$ in diameter, which are usually referred to as garnet neoblasts and megablasts, respectively.

The modal abundance of garnet and quartz is highly variable, suggesting local differences in the bulk chemistry of the protolith. On this basis, two groups of whiteschists can be distinguished: $\mathrm{SiO}_{2}$-rich and $\mathrm{SiO}_{2}$-poor (Chopin 1984; Hermann 2003; Schertl and Schreyer 2008; Ferrando et al. 2009; Gauthiez-Putallaz et al. 2016). In the $\mathrm{SiO}_{2}$-rich whiteschist, garnet forms millimetre-sized crystals and the surrounding rock matrix consists mainly of a large amount ( $>40 \%$ ) of quartz (former coesite), followed by kyanite and phengite. In the $\mathrm{SiO}_{2}$-poor whiteschists, garnet forms very large crystals (up to $20 \mathrm{~cm}$ across) and the rock matrix presents a larger amount of kyanite and phengite (see also Simon et al. 1997; Simon and Chopin 2001). In these rock types, coesite occurs as an inclusion only in garnet rims and small amounts of quartz are present in the rock matrix. In this work, we focus on garnet megablasts from the $\mathrm{SiO}_{2}$-poor whiteschists because they host numerous solid inclusions, thus appearing particularly suitable for the application of elastic thermobarometry.

\section{Petrography and selection of solid inclusions in garnet}

The solid inclusions in garnet megablasts mainly consist of kyanite, rutile, zircon, rare coesite (the latter only found at the megablast rims), biotite, chlorite, apatite and subordinate rare phases such as ellenbergerite and dumortierite (see also Chopin 1984; Schertl et al. 1991). Some minerals found as inclusions, such as biotite, are absent in the rock matrix. Among our samples, the garnet megablasts coming from the Gilba locality are generally less affected by late-stage chloritization compared to those from Martiniana and contain a larger number of rutile and zircon inclusions. Moreover, garnets from the two localities also differ in crystal shape; those from Gilba being spherical whereas idiomorphic or sub-idiomorphic garnets are found at Martiniana.

Among all of the solid inclusions hosted in the pyrope megablasts, zircon is the only one suitable for elastic thermobarometry. Rutile cannot be used because rutile inclusions do not show any residual pressure at room conditions due to the contrast in the elastic properties of rutile to those of its garnet host (Musiyechenko et al. 2020). Coesite is commonly back-reacted to quartz while kyanite is too large with respect to the host garnet and it is usually itself full of solid and fluid inclusions. Moreover, although quartz is abundant in the rock matrix, it is almost absent as single crystalline inclusions: we found only one grain, and it was exposed to the external surface of a thin section. Zircon inclusions were selected for study according to the "geometrical" requirements given by Mazzucchelli et al. (2018) and Campomenosi et al. (2018), that they should be isolated at a distance at least three times the inclusion radius or major axis from any kind of discontinuity (host surfaces, fractures) or other inclusions, and of regular inclusion shape, from approximately spherical to ellipsoidal. Only inclusions with widths (full width at half maximum FWHM) of less than $5 \mathrm{~cm}^{-1}$ for their Raman peak near $1008 \mathrm{~cm}^{-1}$ were measured to avoid inclusions affected by significant radiation damage (Campomenosi et al. 2020b).

\section{Material and methods}

\section{Electron microprobe and LA-ICP-MS}

Microprobe analyses were carried out with a JEOL JXA 8200 electron microprobe at the University of Milan (Earth Science Institute) using wavelength dispersive spectrometers. The electron microprobe analyses and chemical element mapping of garnet were done with an acceleration voltage of $15 \mathrm{kV}$ and a beam current of $40 \mathrm{nA}$. The measurements of all elements were performed with a 30 s counting time while background-counting time was $10 \mathrm{~s}$ for the positive and negative part each. Natural standards used for quantification are: omphacite for $\mathrm{Na}$, ilmenite for $\mathrm{Ti}$, rhodonite for $\mathrm{Mn}, \mathrm{K}$-feldspar for $\mathrm{K}$, olivine for $\mathrm{Mg}$, grossular for $\mathrm{Si}, \mathrm{Ca}$ and $\mathrm{Al}$, fayalite for $\mathrm{Fe}$ and pure $\mathrm{Cr}$ metal for $\mathrm{Cr}$. 
The chemical compositions of partially exposed zircon and rutile inclusions as well as garnet hosts were measured by LA-ICP-MS with a Resonetics RESOlutionSE 193 nm excimer laser system equipped with an S-155 large-volume constant-geometry chamber (Laurin Technic, Australia) at the Institute of Geological Sciences, University of Bern, Switzerland. The laser system was coupled to an Agilent 7900 quadrupole ICP-MS instrument. The spot size on the zircon crystals was $20 \mu \mathrm{m}$ while those on rutile and garnet crystals was $64 \mu \mathrm{m}$. Standards for garnet trace elements were GSD-1 g (primary), NIST 612 (secondary), primary and secondary standard for rutile and zircon trace elements were NIST 610, GSD-1G and NIST 612, Zircon 91,500, respectively. Stoichiometric Si was employed as an internal standard for both zircon $\left(\mathrm{SiO}_{2}: 31.6 \mathrm{wt} \%\right)$ and garnet $\left(\mathrm{SiO}_{2}\right.$ : $43.9 \mathrm{wt} \%$ ) while for rutile stoichiometric $\mathrm{TiO}_{2}$ (99 wt\%) was used. Reproducibility and accuracy were within $10 \%$ or better for all analyzed elements. The data were reduced with the freeware Iolite (Hellstrom et al. 2008; Paton et al. 2011) using the data reduction scheme for trace elements of Woodhead et al. (2007).

\section{Phase equilibria modelling and Zr-in-rutile geothermometry}

Phase equilibria modelling was carried out by means of Gibbs free energy minimization using the software Perple_X (version 6.6.8; Connolly 2005, 2009) and the thermodynamic database of Holland and Powell (2011). In agreement with previous studies (Schreyer 1988; Hermann 2003; Gauthiez-Putallaz et al. 2016), the whiteschists can be successfully modelled by the KFMASH chemical system $\left(\mathrm{K}_{2} \mathrm{O}-\mathrm{FeO}-\mathrm{MgO}-\mathrm{Al}_{2} \mathrm{O}_{3}-\mathrm{SiO}_{2}-\mathrm{H}_{2} \mathrm{O}\right)$. However, the presence of garnet megablasts within the rock complicates the choice of a representative reactive bulk chemistry. As described in Sample description, one major variable in the Dora-Maira whiteschists is the amount of bulk $\mathrm{SiO}_{2}$. For instance, the large garnet megablasts are referred to as $\mathrm{SiO}_{2}$ poor whiteschists (e.g., Chopin 1984; Schertl and Schreyer 2008). Therefore, a series of $T$ - $X_{\text {bulk }}$ content (wt $\%$ ) and $T$-bulk Mg\# pseudosections have been computed at different $P$. The final bulk chemistry we used for our modelling is: 50 wt $\% \mathrm{SiO}_{2}, 26 \mathrm{wt} \% \mathrm{Al}_{2} \mathrm{O}_{3}, 1.5 \mathrm{wt} \% \mathrm{FeO}, 16.5 \mathrm{wt} \% \mathrm{MgO}$ and $6 \mathrm{wt} \% \mathrm{~K}_{2} \mathrm{O}$ with water in excess. This bulk chemistry differs from the one of $\mathrm{SiO}_{2}$-poor whiteschists given by GautiezPutallaz et al. (2016) in the $\mathrm{Mg} \#$ that is 0.9 rather than 0.8 (see the Supplementary material for further details). Information on the activity-composition relationships for mineral solid solutions are given in the Supplementary material.

Because in our samples zircon is the only suitable inclusion for elastic thermobarometry, we need another independent constraint to define unique points in $P-T$ space. To this purpose, we used the $\mathrm{Zr}$ concentration in rutile inclusions as a geothermometer (Tomkins et al. 2007) assuming that, after entrapment, the garnet-rutile system remained isolated from the surrounding environment.

\section{Raman spectroscopy}

Raman measurements were performed with a Horiba Jobin-Yvon T64000 triple-monochromator spectrometer operating in a subtractive mode equipped with a Symphony LN2-cooled CCD detector, 1800-gr/mm holographic gratings, an Olympus $\mathrm{BH}-41$ optical microscope with a $50 \times$ long-working distance objective and a Coherent Ar+laser at the Department of Earth Sciences of the University of Hamburg (Germany). The spectral resolution was $2 \mathrm{~cm}^{-1}$. The laser power delivered to the sample was approximately $8 \mathrm{~mW}$, which was sufficient to avoid overheating of the examined zircon grains (Zhong et al. 2019). The instrumental precision in the peak position determination is about $0.35 \mathrm{~cm}^{-1}$. For details on Raman spectra processing and evaluation, see the Supplementary material.

\section{Determination of residual strain and residual pressure of zircon inclusions}

The independent residual strain components (i.e., $\varepsilon_{1}$ and $\varepsilon_{3}$ ) and residual volume strain in zircon inclusions were calculated via the Grüneisen tensor approach (e.g., Murri et al. 2018; Angel et al. 2018) using four different zircon phonon modes: the $\mathrm{B}_{1 \mathrm{~g}}$ mode near $1008 \mathrm{~cm}^{-1}$, the $\mathrm{A}_{1 \mathrm{~g}}$ mode near $975 \mathrm{~cm}^{-1}$, the $E_{\mathrm{g}}$ mode near to $357 \mathrm{~cm}^{-1}$ and the $A_{1 \mathrm{~g}}$ mode near to $440 \mathrm{~cm}^{-1}$. Grüneisen tensor coefficients for each mode are from Stangarone et al. (2019). Once the strain was determined, we defined the independent stress components and the inclusion residual pressures (i.e., the negative of the mean normal stresses) with EntraPT, an online platform for elastic thermobarometry (Mazzucchelli et al. 2021) using the zircon stiffness tensor given by Özkan et al. (1974). Residual pressures were also calculated using the hydrostatic pressure calibrations of the Raman shifts (Binvignat et al. 2018).

\section{Results}

\section{Garnet mineral chemistry and $\mathrm{Zr}$ concentration in rutile inclusions}

\section{Garnet}

Table 1 lists representative microprobe analyses of the three garnet megablasts (samples DM17-13, DM17-35 and DMG4-5). Samples DM17-13 from Martiniana and DMG4-5 from the Gilba locality display a chemical zonation with decreasing almandine and grossular content from 


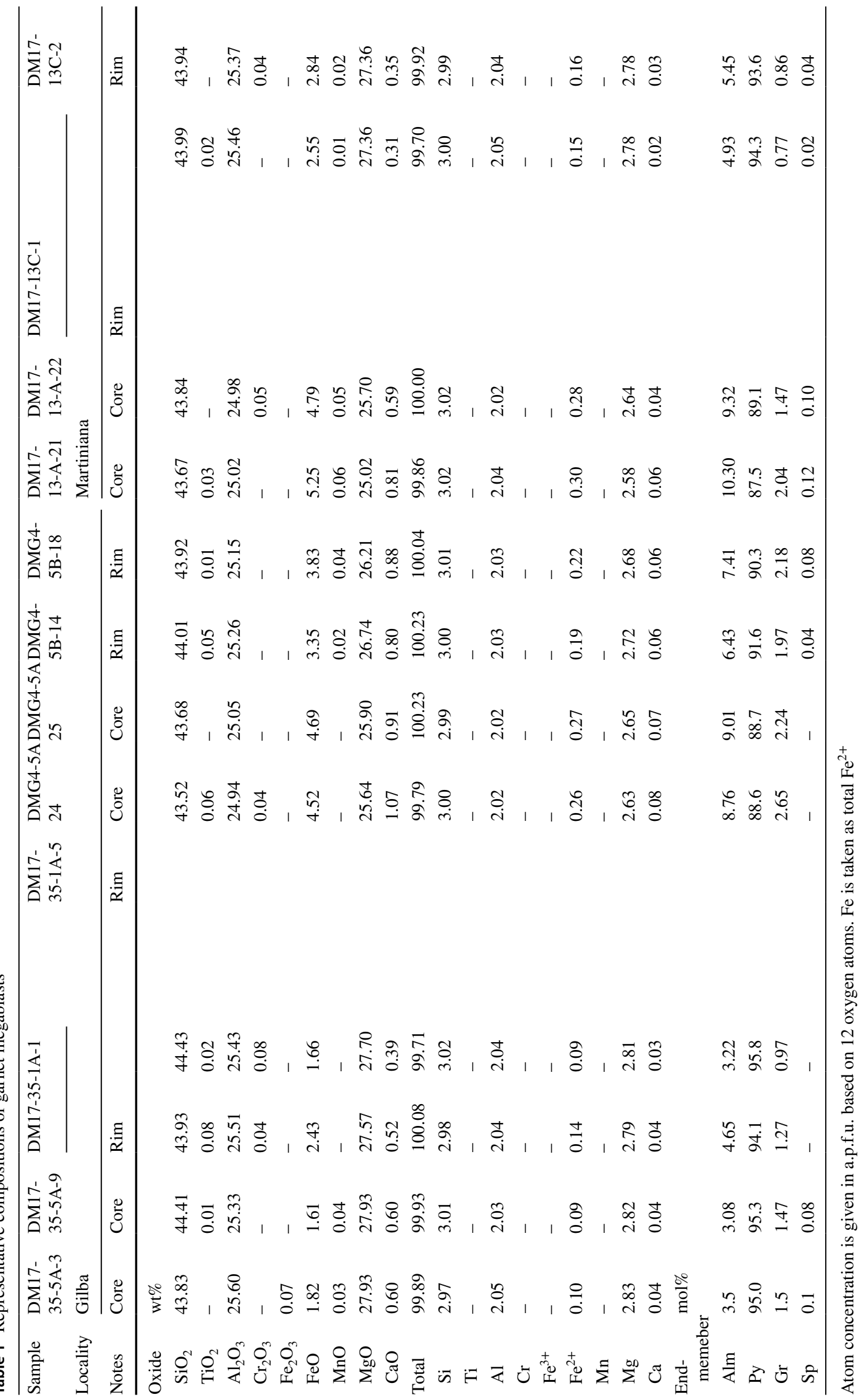


core to rim and increasing pyrope from about $88 \mathrm{~mol} \%$ to about $96 \mathrm{~mol} \%$. In contrast, sample DM17-35 is homogeneous in composition with constant pyrope content of about $94 \mathrm{~mol} \%$ from core to rim. The spessartine content in the garnet megablasts is generally below $1 \mathrm{~mol} \%$ and Mn concentration decreases from core to rim. Figure 2a shows and compares the core to rim variation of pyrope content for the three megablasts.

The garnet DM17-13 (Martiniana locality) shows the highest HREE content variation with normalized Lu content ranging from about 1000 to 70 from core to rim, respectively (full and empty symbols, respectively, in Fig. 2b). The core of garnet DM17-13 also shows the highest concentration of REE with respect to the other two megablasts, with a difference of about one order of magnitude (Fig. 2b). In contrast, garnets DMG4-5 and DM17-35 (Gilba locality) show flatter
HREE patterns at the crystal core with slight HREE depletion towards the rim (Fig. 2b).

In principle, the presence of zircon and apatite inclusions enables the use of $\mathrm{Zr}$ and $\mathrm{P}$ concentrations in garnet as indicators of $P$ and $T$ conditions during growth (Kohn et al. 2015; Hermann and Spandler 2008). Figure 2c shows the $\mathrm{Zr}$ vs. $\mathrm{P}$ concentration for the different domains (core and rim) of the three garnet megablasts. Sample DM17-13 shows a slight core to rim increase in $\mathrm{Zr}$ (full and empty grey squares, respectively), at the same $P$ concentration, whereas samples DM17-35 and DMG4-5 show no clear compositional difference between core and rim (Fig. 2c).
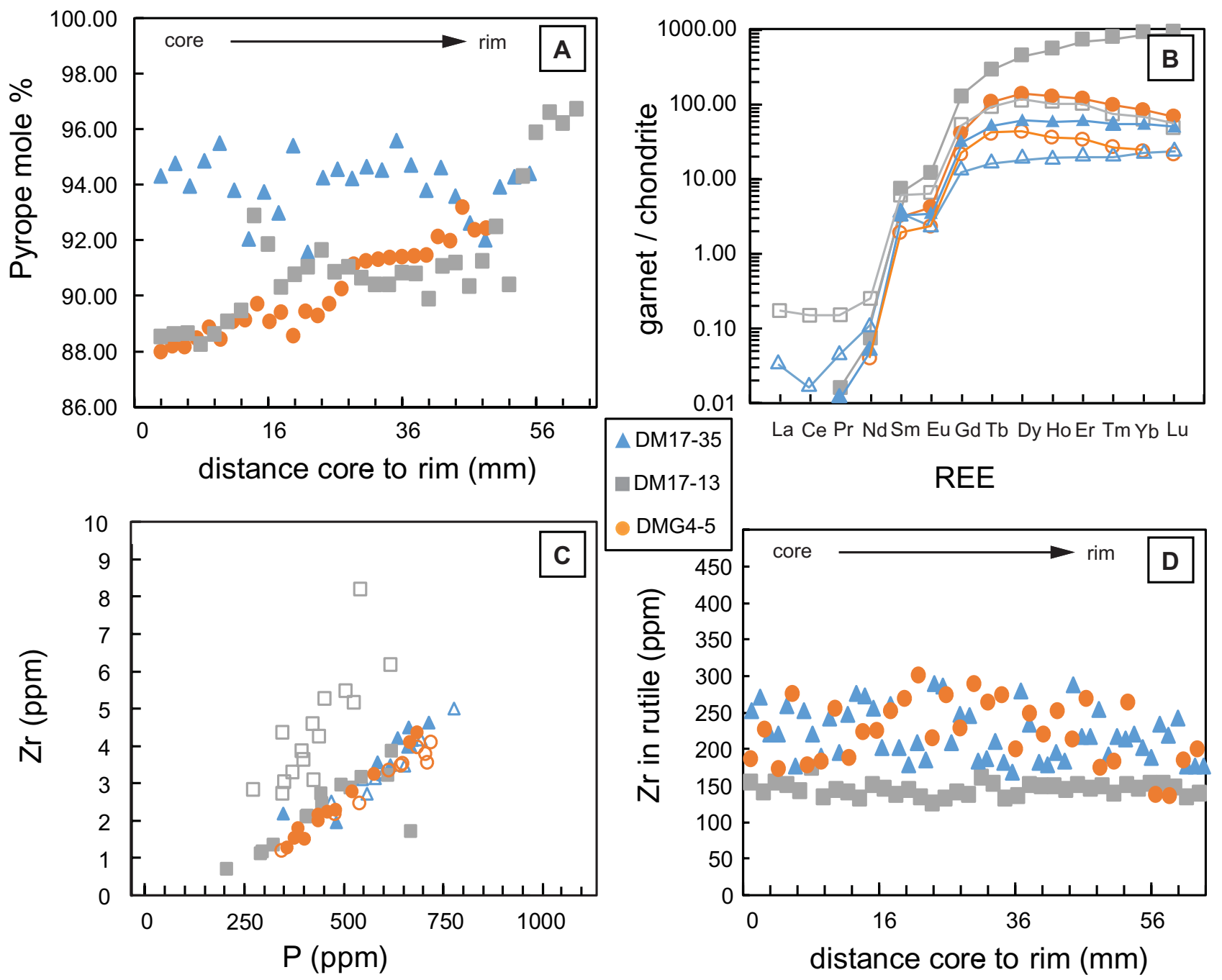

Fig. 2 a pyrope content, b REE patterns, $\mathbf{c} \mathrm{Zr}$ vs. P concentration and $\mathbf{d} \mathrm{Zr}$ concentration of rutile inclusions within the three garnet megablasts along core to rim transects (full and empty symbols represent measurements at the garnet core and rim, respectively) 
Table $2 \mathrm{Zr}$ concentration in rutile inclusions (LA-ICP-MS data)

\begin{tabular}{llll}
\hline Sample & $\begin{array}{l}\text { DM17-35 } \\
\text { Gilba }\end{array}$ & $\begin{array}{l}\text { DMG4-5 } \\
\text { Gilba }\end{array}$ & $\begin{array}{l}\text { DM17-13 } \\
\text { Martiniana }\end{array}$ \\
\hline Average Zr conc. (ppm) & 220 & 216 & 144 \\
Min-max values (ppm) & $169-275$ & $134-288$ & $125-174$ \\
e.st.dev. (ppm) & 35 & 58 & 9 \\
No. of measurements & 53 & 33 & 38 \\
\hline
\end{tabular}

\section{Rutile inclusions in garnet}

Table 2 lists the mean concentration values and relative standard deviation of $\mathrm{Zr}$ concentration obtained by LA-ICPMS in rutile inclusions within the three garnet hosts. Sample DM17-13 (Martiniana) shows an average concentration of 144 ppm while samples DM17-35 and DMG4-5 (both Gilba) have 220 and $216 \mathrm{ppm}$, respectively. Multiple measurements on the largest crystals of rutile revealed no detectable chemical zoning within single grains.

\section{Zr in rutile thermometry and pseudosection modelling of garnet growth}

The intersection between the $P-T$ lines indicated by $\mathrm{Zr}$-inrutile thermometry and the pyrope isopleths constrains the growth of the three garnet megablasts to about 3-3.5 GPa and $675-720^{\circ} \mathrm{C}$ (Fig. 3b).

The lower and upper $T$ limits correspond to the differences in the average $\mathrm{Zr}$ concentration found in the rutile inclusions in each garnet megablast. The application of the $\mathrm{Zr}$-in-rutile thermometry requires that a $\mathrm{SiO}_{2}$ is present. Coesite was found in the garnet rim and $\mathrm{SiO}_{2}$ saturation is achieved through the reaction of talc + kyanite to give garnet + coesite (e.g. Gauthiez-Putallaz et al. 2016). Therefore, the $\mathrm{Zr}$-in-rutile temperatures for inclusions in the garnet rims are accurate and these values are reported in Fig. 5. For rutile trapped in the interior, the $\mathrm{SiO}_{2}$ activity is below unity (but buffered by the assemblage talc-kyanite-pyrope) and these temperatures represent maximum values. We did not note a systematic change in $\mathrm{Zr}$ contents of rutile in different positions within the garnet megablasts (Fig. 2d), indicating that the analytical scatter is larger than the effect of $\mathrm{SiO}_{2}$-activity below unity. The difference of $\mathrm{Zr}$ content in rutile between the garnets from the two different localities cannot be readily explained by differences in $\mathrm{SiO}_{2}$-activity since no quartz/
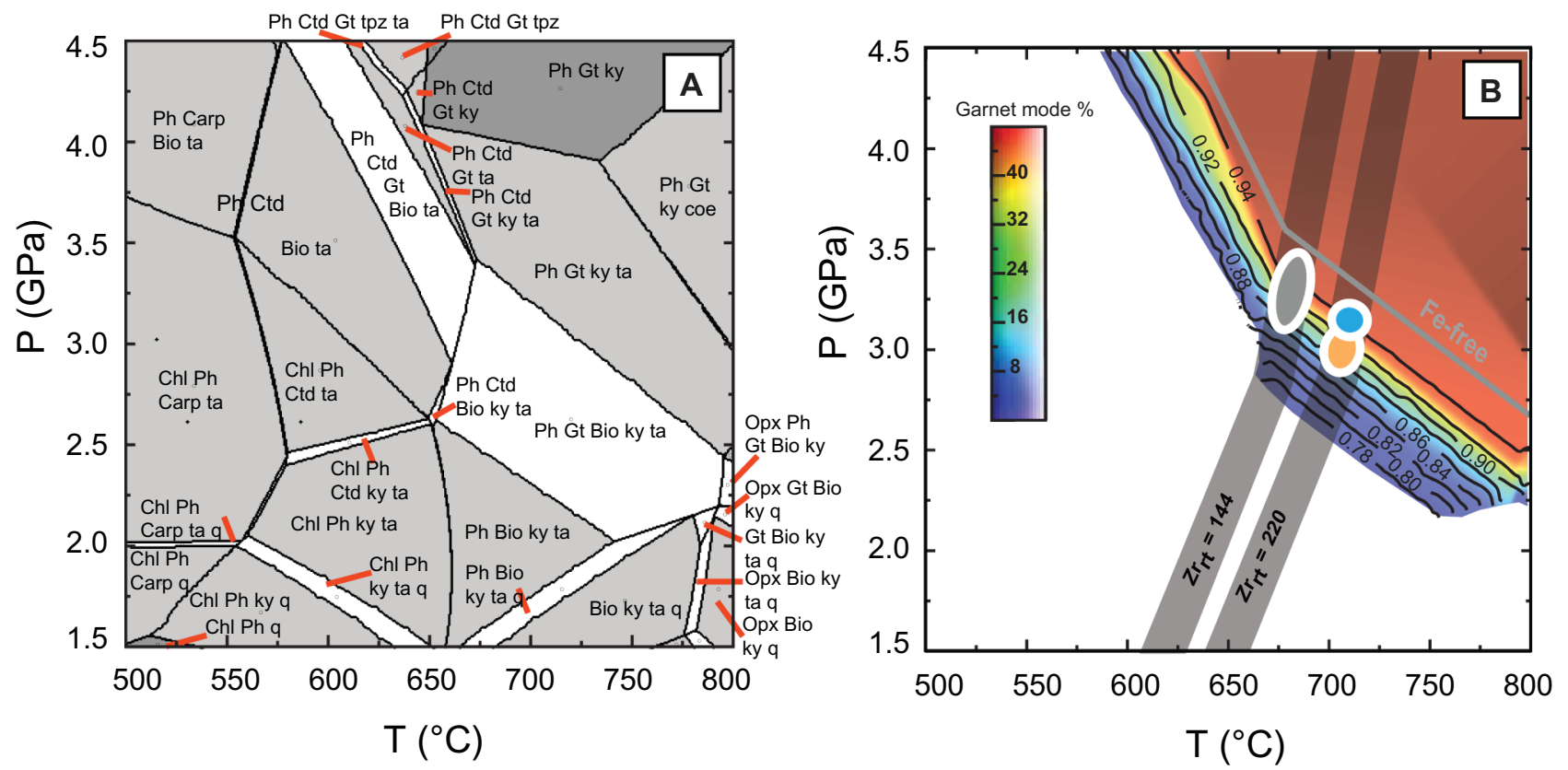

Fig. 3 a Pseudosection modelling of $\mathrm{SiO}_{2}$-poor whiteschists. b Combination of $\mathrm{Zr}$-in-rutile thermometer (line thickness indicates the $T$ uncertainty) and computed isopleths of pyrope (labelled in mole fraction) in garnet (black labeled lines) to constrain the conditions of garnet growth, indicated by the three colored ellipses (DM17-13 in grey, DM17-35 in blue, DMG4-5 in orange). The garnet stability field is also color-coded by its mode as indicated in the legend. The Fe-free line represents the garnet-in phase boundary computed for a Fe-free bulk composition, to take into account possible effects of fractionation that otherwise are neglected. Note that the $P-T$ range of garnet growth indicated by the garnet composition and the $\mathrm{Zr}$ content of rutile corresponds to a significant increase of the garnet mode (from $5-8 \%$ to about $45 \%$ ) in agreement with the observed growth of garnet megablasts 

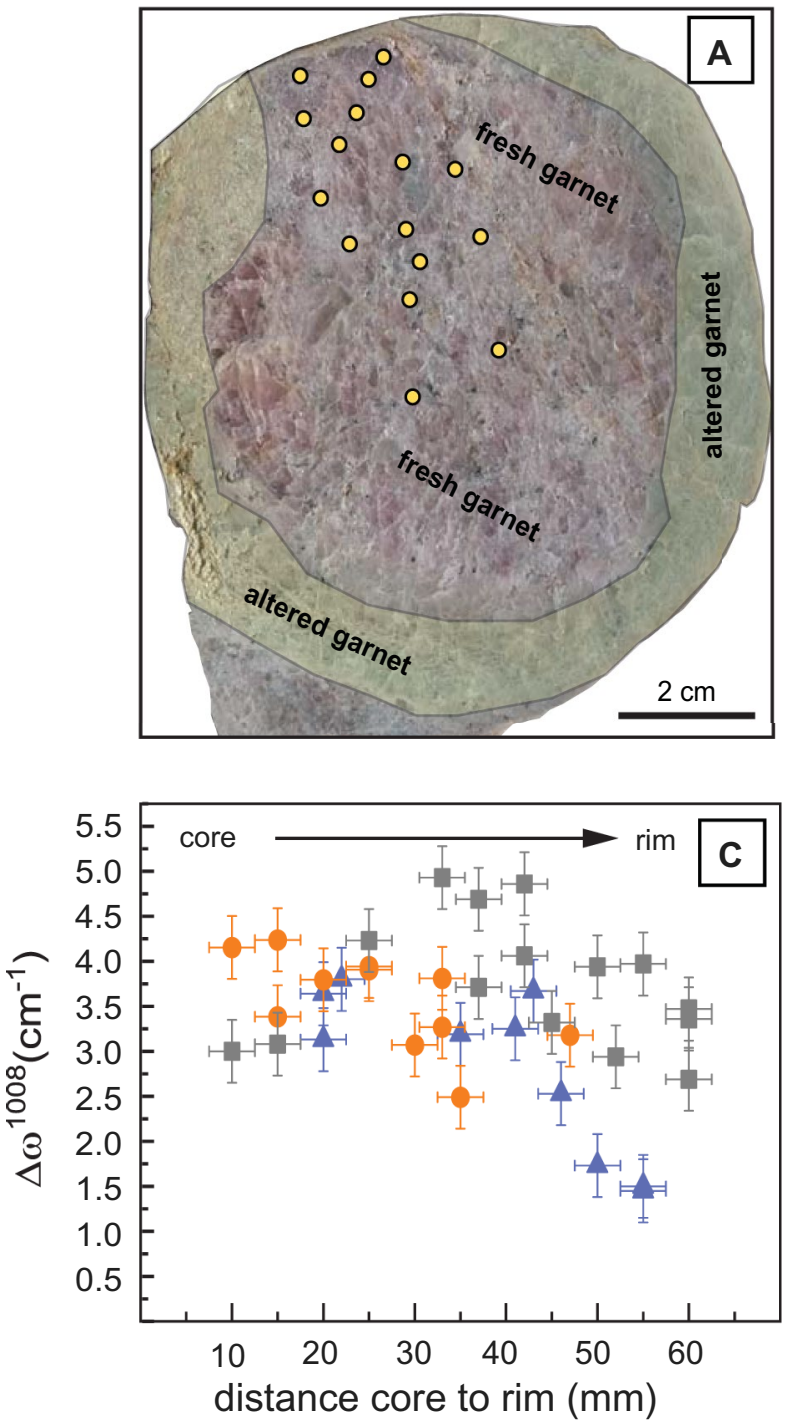

Fig. 4 a Equatorial slice of a garnet megablast (sample DM17-13, Martiniana locality), with the location of selected zircon inclusions indicated by yellow spots covering the entire range of garnet growth. b Completely buried zircon inclusion viewed under crossed (top) and plane (bottom) polarized light showing the characteristic stress-induced birefringence halo in the surrounding host. $\mathbf{c}$ Changes

coesite occurs in any of the garnet cores and requires further investigation. It is possible that the temperatures of garnet growth in the two localities that we have studied are actually the same. Recent data on $T$ dependence of $\mathrm{Zr}$ concentration within garnet by Kohn et al. (2015) would yield a similar $T$ range of garnet growth.

\section{Residual strain and residual pressure of zircon inclusions from Raman spectroscopy}

Selected zircon inclusions were measured to cover the entire range of garnet growth as reported in Fig. 4a. All measured

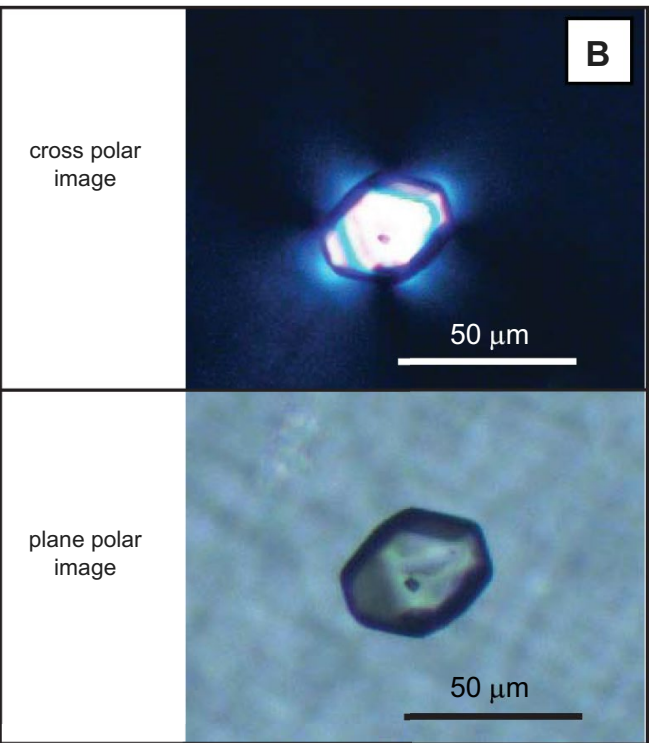

DDM17-13

DMG4-5

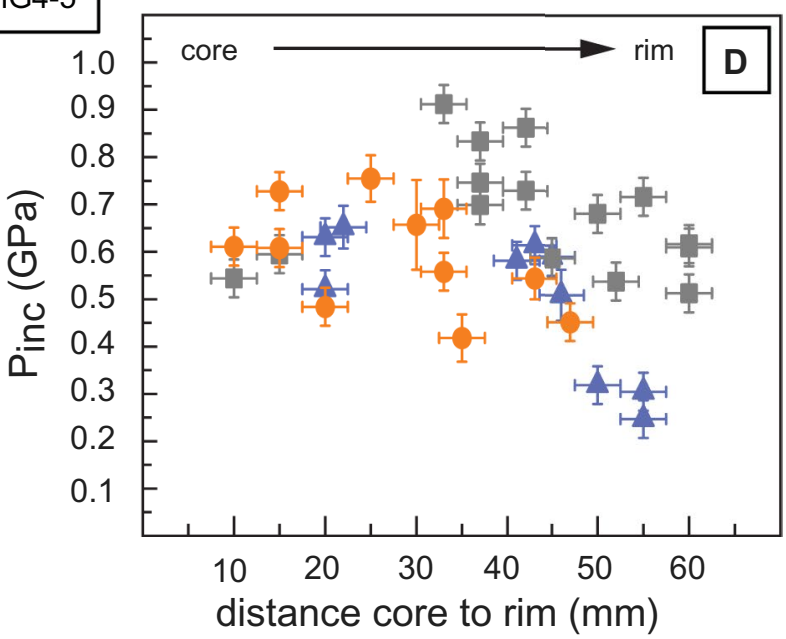

in the peak position (i.e., $\Delta \omega$ ) of the $\mathrm{B}_{1 \mathrm{~g}}$ mode near $1008 \mathrm{~cm}^{-1}$ of completely buried zircon inclusions entrapped within the three garnet megablasts plotted against their distance from the core of the host crystal. d Calculated residual pressure from Raman measurements as function of the position within the garnet host from the three garnet megablasts

inclusions show the typical "rosette" birefringence of the garnet host immediately surrounding the stressed inclusions (Fig. 4b), which is the result of the local symmetry breaking of the garnet host due to the stress field developed around inclusions (e.g., Howell et al. 2010; Campomenosi et al. 2020a).

Figure $4 \mathrm{c}$ shows the changes in the Raman peak position (i.e., $\Delta \omega$ ) for the zircon $\mathrm{B}_{1 \mathrm{~g}}$ phonon mode near $1008 \mathrm{~cm}^{-1}$ with respect to a free zircon crystal taken as reference. The residual pressures resulting from the Raman measurements are shown in Fig. 4d. Note that, within data uncertainty, there is no difference between the zircon residual pressures 


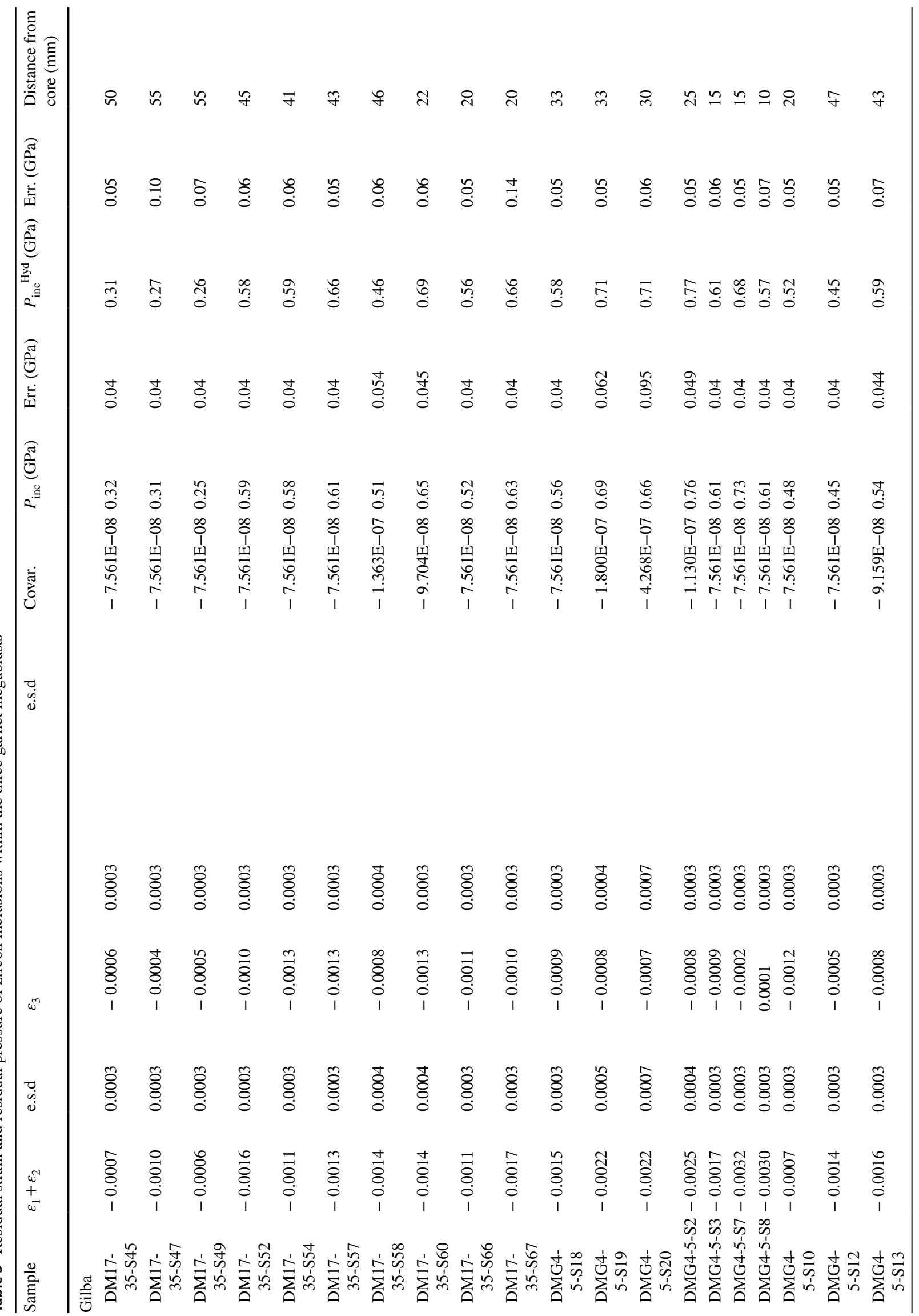




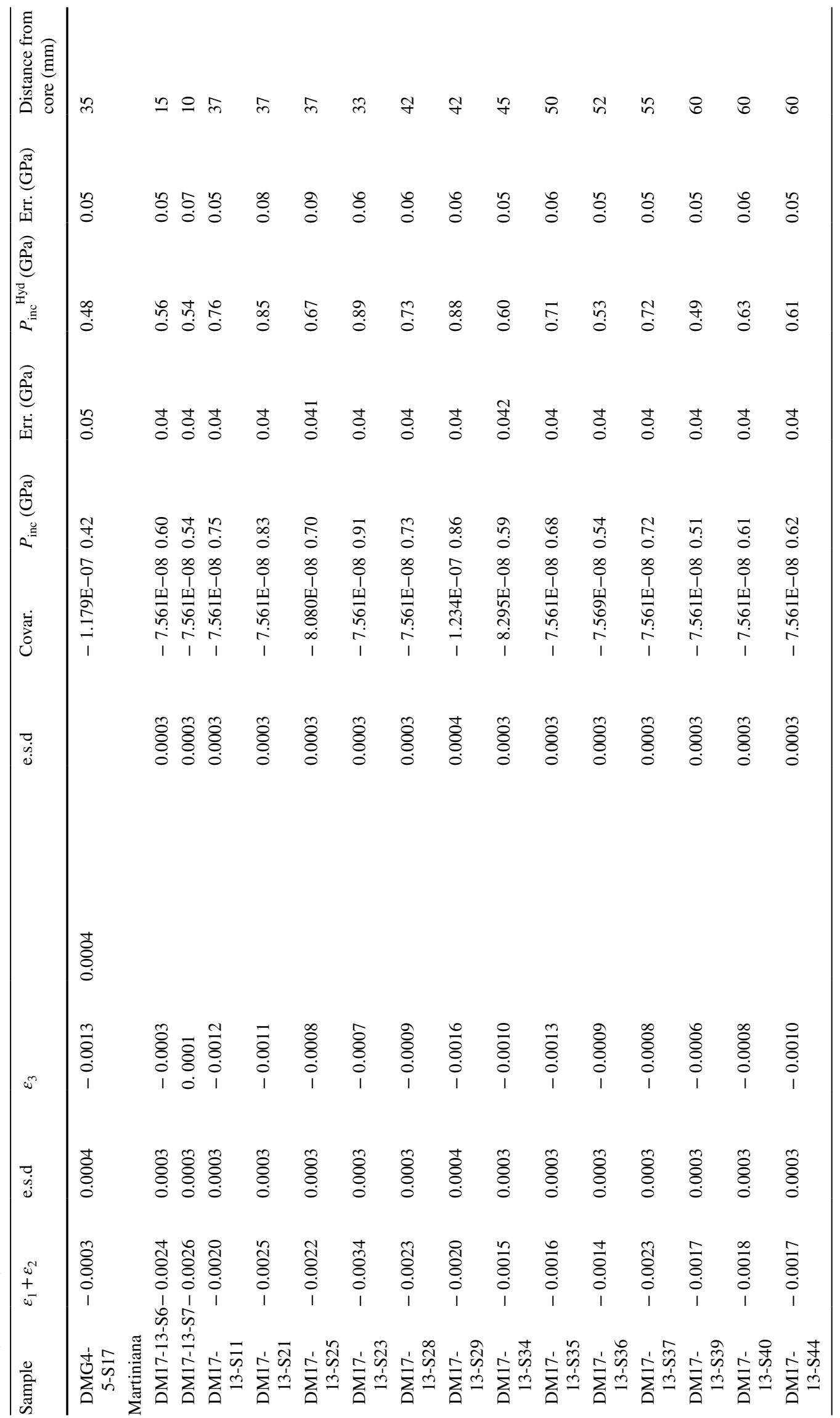




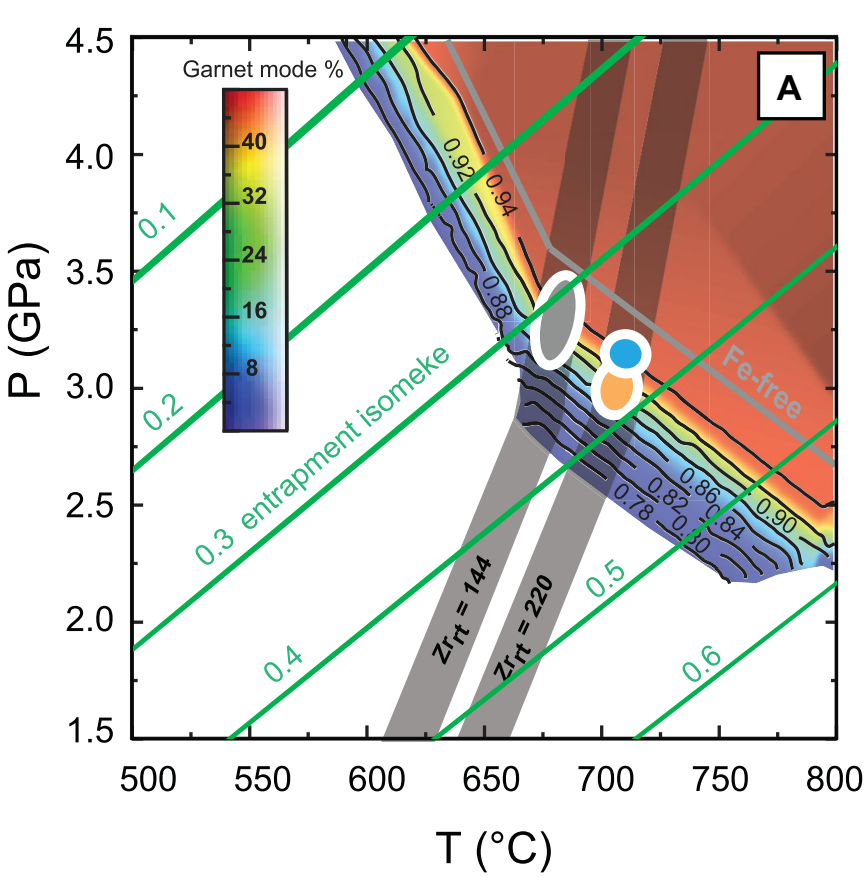

Fig. 5 a Garnet and Zr-in-rutile isopleths (from Fig. 3b) compared with calculated zircon-in-garnet isomekes labelled by the $\mathrm{P}_{\text {inc }}$ (given in $\mathrm{GPa}$ ) of zircon inclusions expected in the recovered samples. $\mathbf{b}$ Data points are the measured zircon inclusion residual pressures (from Fig. 4d, Table 3) with their weighted mean indicated by the

computed using the hydrostatic and the Grüneisen tensor approaches (Table 3). In general, the residual pressure values vary considerably from core to rim of the garnet megablasts. Sample DM17-35 shows an average value of about $0.6 \mathrm{GPa}$ up to about $45 \mathrm{~mm}$ of distance from the crystal core and then a drop to an average value of about $0.3 \mathrm{GPa}$ from 45 to $55 \mathrm{~mm}$. Sample DMG4-5 displays more variation in residual pressure values, ranging from 0.75 to $0.45 \mathrm{GPa}$ with a slightly decreasing trend from core to rim. On the other hand, sample DM17-13 displays a bell-shaped trend moving from core to rim with residual pressures of about 0.6 $\mathrm{GPa}$ at the garnet core (i.e., 10 and $20 \mathrm{~mm}$ ), a peak value of about $0.9 \mathrm{GPa}$ around $35 \mathrm{~mm}$ and a decreasing trend moving toward the external rim down to about $0.6-0.65 \mathrm{GPa}$ (Fig. 4d).

Overall, the mean residual pressure value for all of the zircon inclusions is about $0.6 \mathrm{GPa}$. If we use this mean value of $P_{\text {inc }}$ combined with the $\mathrm{Zr}$-in-rutile thermometry the calculated entrapment conditions would be below $1.5 \mathrm{GPa}$ and $650^{\circ} \mathrm{C}$. On the other hand, if we combine the average $P_{\text {inc }}$

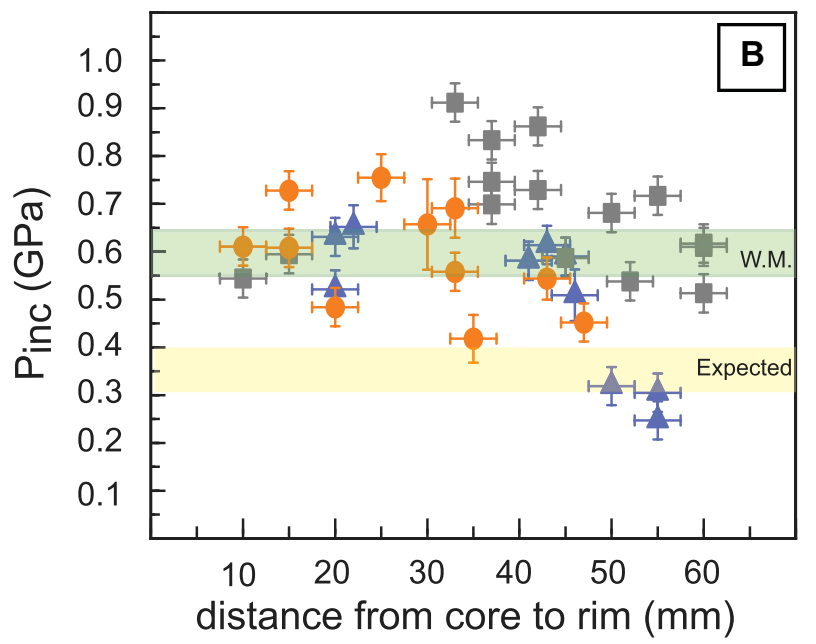

green band labelled 'W.M.'. The yellow band indicates the $\mathrm{P}_{\text {inc }}$ calculated for zircon inclusions entrapped at the $P-T$ conditions shown in a, assuming hydrostatic stress conditions during entrapment and purely elastic behavior during the subsequent metamorphic history and exhumation

with the pyrope isopleths the calculated entrapment conditions would be $2-2.5 \mathrm{GPa}$ and above $800{ }^{\circ} \mathrm{C}$.

\section{Discussion}

These Dora-Maira pyrope megablasts provide an excellent natural laboratory to investigate the relationship between chemical and mechanical equilibration of garnet. The large garnets allow multiple zircon inclusions to be measured from core to rim of their host and can be compared with the well-constrained $P-T$ conditions of garnet formation. The $P-T$-time path of the rocks is also well constrained (e.g., Gebauer et al. 1997; Rubatto and Hermann 2001) and includes first a pressure increase to about 3.5-4 GPa, $720-750{ }^{\circ} \mathrm{C}$ followed by near isothermal decompression to $0.5 \mathrm{GPa}, 600-650{ }^{\circ} \mathrm{C}$ resulting in significant differences in the garnet-zircon isomekes between entrapment and the later metamorphic evolution. This provides the opportunity to thoroughly assess to what extent the entrapment conditions 

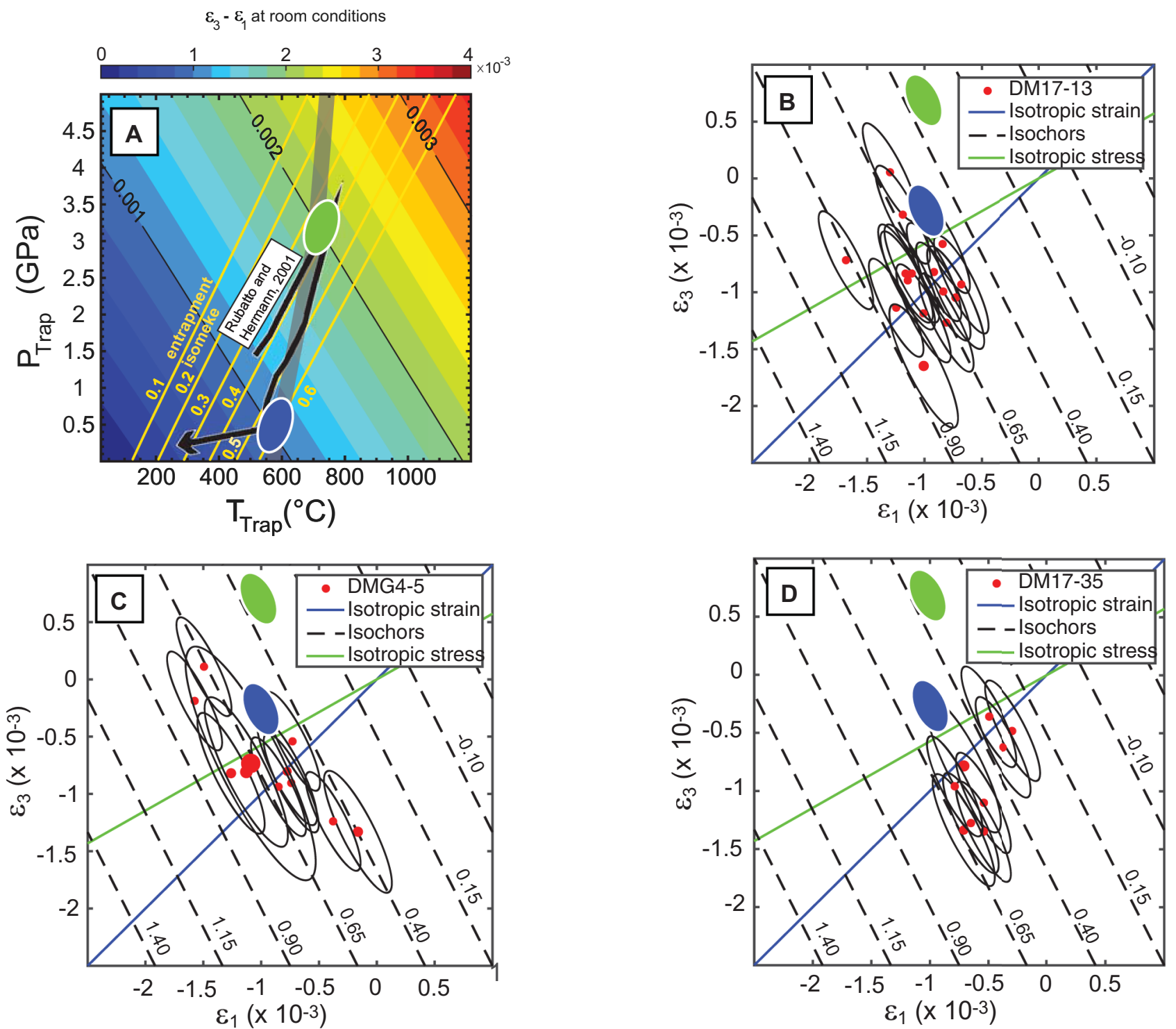

Fig. 6 a Contour map of the calculated deviatoric strain $\left(\varepsilon_{3}-\varepsilon_{1}\right)$ expected at room conditions for zircon inclusions within garnet as a function of inclusion entrapment conditions. Calculations assume a spherical shape of the inclusion, a hydrostatic stress during entrapment and a purely elastic behavior of the host-inclusion system (Mazzucchelli et al. 2019). Colour scale for the contours is given at the top of the diagram. Yellow solid lines represent the zircon-in-garnet entrapment isomekes for the range of measured inclusion residual pressures. The green and the blue ellipses represent respectively the conditions of inclusion entrapment according to the pseudosection modelling and the conditions of entrapment according to the inter-

are preserved, which might be difficult to detect in systems with a smaller drop in pressure. In the following, we will first compare the results from chemical and elastic thermobarometry. Then the observed strain data are compared to predictions from numerical models. Finally, possible factors are discussed to explain the discrepancy between results from chemical and elastic thermobarometry.

section between the average entrapment isomeke and the $P-T$ path of Rubatto and Hermann (2001) (solid black arrow). b-d display the zircon inclusion strains $\varepsilon_{3}$ and $\varepsilon_{1}$ within the three garnet megablasts calculated via the Grüneisen tensor approach from Raman measurements. The green and blue ellipses represent the modelled strain states of zircon inclusions in garnet for the corresponding $P, T$ conditions in $\mathbf{a}$. The size of confidence ellipses refers to $1 \sigma$. Black dashed lines represent the conditions of equal volume strain (i.e., isochores), they are labeled with the corresponding residual pressure given in $\mathrm{GPa}$

\section{Combining chemical and elastic thermobarometry}

Chemical homogenization during the metamorphic thermal peak is negligible for big crystals (e.g., Spear and Peacock 1989) such as the pyrope megablasts from the DoraMaira whiteschists. Therefore, the zonation in major and trace elements of garnet, combined with the pseudosection 
modelling, suggest garnet growth in a relatively small prograde interval of $P-T$ conditions within the coesite stability field.

Figure 5a shows the results of phase equilibria modelling of the garnet stability together with $\mathrm{Zr}$-in rutile thermometry and the entrapment isomekes for the range of zircon residual pressures (in GPa) that we measured. The entrapment isomeke for a given $P_{\text {inc }}$ represents possible conditions of inclusion entrapment or elastic re-equilibration (e.g., Angel et al. 2015; Ferrero and Angel 2018). From Fig. 5a, the slopes of zircon-in-garnet isomekes and $\mathrm{Zr}$-in-rutile isopleths allow us to define the garnet growth in terms of $P-T$ conditions for inclusion entrapment independently from the garnet composition. However, for entrapment at the conditions determined by the thermodynamic modelling, the expected range of zircon inclusion residual pressure should be between 0.4 and $0.3 \mathrm{GPa}$. But only a few inclusions along the rims of garnet samples DM17-35 and DMG4-5 exhibit such pressures. On the other hand, most inclusion residual pressures are between 0.55 and $0.65 \mathrm{GPa}$ (green band in Fig. 5b) with a weighted mean of $0.6 \mathrm{GPa}$. These values, in combination with the $\mathrm{Zr}$-in-rutile thermometry, would correspond to entrapment conditions far below the stability fields of both garnet and coesite. This is not consistent with the petrographic observations. Moreover, from Fig. 5a we can rule out the possibility of garnet-forming reaction overstepping as a possible explanation of residual pressure changes. Indeed, for a prograde garnet growth, as in this case of study, the pressure in the inclusions would be lower than expected. Therefore, the deviation of most measured $P_{\text {inc }}$ values from those expected for the $P-T$ conditions of entrapment needs to be evaluated in a different way.

\section{Combining residual strain from Raman spectroscopic measurements and residual strain from selected numerical models}

In addition to giving the residual inclusion pressures, the Raman measurements also give their residual strains, expressed in terms of their independent components $\varepsilon_{3}$ and $\varepsilon_{1}$. These can be compared to calculations of the strain in zircon inclusions via numerical simulations (e.g., Mazzucchelli et al. 2019). Figure 6 a shows the contour map of deviatoric strain (i.e., $\varepsilon_{3}-\varepsilon_{1}$ ) computed for zircon inclusions in garnet at room $P$ and $T$ as function of metamorphic entrapment conditions (i.e., $P_{\text {trap }}$ and $T_{\text {trap }}$ ). Note that such a contour map is obtained assuming (i) a purely elastic behavior of the host-inclusion system; (ii) a hydrostatic stress conditions at the moment of entrapment and (iii) a spherical shape of the inclusion (see Mazzucchelli et al. 2019). Here, the range of zircon-in-garnet isomekes, of interest for these garnet megablasts, and the Dora-Maira $P-T$ path (Rubatto and Hermann 2001) are superimposed for reference. The green ellipse in Fig. 6a indicates the conditions of garnet growth on the prograde path as suggested by chemical thermobarometry (3-3.5 GPa and $675-720^{\circ} \mathrm{C}$ ), while the blue ellipse in Fig. 6a represents the intersection of the known $P-T$ path with the isomeke corresponding to the mean residual inclusion pressure of $0.6 \mathrm{GPa}$, at about $575-600^{\circ} \mathrm{C}$ and $0.5 \mathrm{GPa}$ along the retrograde evolution of the UHP unit.

In Fig. 6b-d, the strains measured by Raman in the zircon inclusions (samples DM17-13, DMG4-5 and DM17-35, respectively) are plotted in $\varepsilon_{3}$ vs. $\varepsilon_{1}$ diagrams.

The residual-independent strain components expected for zircons trapped during garnet growth on the prograde path (green ellipse) are significantly different from those measured in the inclusions (red dots in Fig. 6b-d). Instead, the blue ellipse in Fig. 6b-d corresponding to the strain conditions expected from the "average isomeke" (i.e., $P_{\text {inc }}=0.6$ $\mathrm{GPa}$ ), is closer to those measured in our zircon inclusions than the green one. Indeed, most of the measured strains, within the data uncertainties, lie close to the lines of isotropic strain and hydrostatic stress conditions (blue and green solid lines respectively in Fig. 6b-d). Note that this is true even for the few zircon inclusions showing residual pressures consistent with the entrapment conditions during the prograde path (i.e., with $P_{\text {inc }}=0.3-0.4 \mathrm{GPa}$ ). These data clearly suggest that other processes than simple entrapment at the inferred conditions have to be considered to explain the evolution of the Dora-Maira host-inclusion systems.

\section{Possible factors influencing zircon residual pressure}

\section{Fluid phase at the host inclusion boundary}

The presence of a fluid film at the host-inclusion boundary will strongly affect both the residual pressure and the strain state of the inclusion (e.g., Nimis et al. 2016). Fluids cannot support shear stresses, and therefore a zircon inclusion surrounded by fluid would exhibit strains (Fig. 6) corresponding to hydrostatic stress. In general, the second effect of water or other fluid phases is to reduce the effective bulk modulus of the composite inclusion with respect to a single-crystal inclusion, thus resulting in an increase in its measured residual pressure. Furthermore, if there was a fluid phase present, this would be expected to result in the incorporation of $\mathrm{OH}$ groups into the crystal structures of both the zircon and the host garnet. The presence of $\mathrm{OH}$ groups in the crystal structure of nominally anhydrous minerals also affects their elastic properties (e.g., Fan et al. 2017) and thus the measured residual inclusion pressure. FTIR spectroscopy measurements and maps on four inclusions showing higher residual pressure, and their surrounding host garnet, showed that no detectable fluid occurs around the inclusions (see Supplementary materials). There is up to $\sim 70 \mathrm{ppm}$ of intracrystalline $\mathrm{OH}$ groups present in the garnet (approximately 0.001 a.p.f.u. $\mathrm{H}$ in the tetrahedral site), but no detectable $\mathrm{OH}$ 
groups in the zircon inclusions. FTIR maps also reveal that the $\mathrm{OH}$ group content in garnet is not related to the presence of the inclusions but it is uniform across the crystal. This level of $\mathrm{H}$ substitution into the garnet structure would not have any significant effect on the equation of state of the garnet (Fan et al. 2017). Hence fluid is not responsible for the anomalously high inclusion pressures, nor their strain state.

\section{Undetectable level of radiation damage in zircon inclusions}

The anomalous increase in inclusion residual pressure could also be due to very low degrees of structural defects due to radiation damage. For example, post-entrapment radiation damage that would cause a free zircon crystal to expand by $0.2 \%$ would increase the inclusion pressure by $\sim 0.3 \mathrm{GPa}$. However, such a low degree of radiation damage cannot be detected by Raman since the corresponding change in the Raman peak width (in terms of FWHM) would be within the instrumental spectral resolution. However, charge-contrast (CC) imaging coupled with LA-ICP-MS analysis, on exposed inclusions in the same garnet hosts, has shown that most zircon grains do not have any radiation damage (Campomenosi et al. 2020b) and therefore radiation damage cannot explain the large number of inclusions with pressures of $>0.6 \mathrm{GPa}$ or more (Fig. 5b).

\section{Local deviatoric stress conditions during entrapment}

As described in Combining residual strain from Raman spectroscopic measurements and residual strain from selected numerical models, a major assumption of the analysis of strains in inclusions (e.g., Fig. 6a) is that the inclusion entrapment occurred under hydrostatic stress conditions (Mazzucchelli et al. 2019). Consequently, the observed divergence of measured strain values from the predicted ones (Fig. 6b-d) might be related to deviations from hydrostatic stress around the inclusions at the time of entrapment. Henry et al. (1993) described the presence of internal S-shaped foliation within the rims of some garnet megablasts that would potentially suggest crystal growth in a stress field. However, no inclusion foliations have been observed in the studied samples. Moreover, garnet formation in these rocks is driven by dehydration reactions producing about 10 vol\% of water (Gauthiez-Putallaz et al. 2016); within such a fluid-rich environment, the development of local deviatoric stress appears to be unlikely. Indeed, for interconnected pore fluids, deviatoric stresses disappear because the rock cannot support shear stress components. On the other hand, if fluids were not interconnected, the mechanism of pressure solution would probably have operated to reduce the deviatoric stresses. In addition, the presence of fluid decreases the amount of stress necessary to develop dislocation creep in crystals (Xu et al. 2013) that, once again, would reduce deviatoric stresses in the garnets. In addition, since our inclusions are randomly oriented within the host, the presence of a local deviatoric stress field at the time of entrapment should scatter the inclusion strains along a single isochore corresponding to a unique volume strain rather than forming a cluster corresponding to isotropic strain or hydrostatic stress conditions. Indeed, under the same amount of deviatoric stress, for inclusions unable to change their orientation according to the stress field, the independent components of the strains would change in absolute values as a function of the crystallographic orientation of the inclusion (Gilio et al. 2020b) keeping the volume strain constant (i.e., lying along one single isochore). Therefore, local deviatoric stress conditions cannot properly explain the strain state of our inclusions.

\section{Post-entrapment plastic relaxation}

The measured strains in all of the inclusions deviate from the strains expected for purely elastic behavior after entrapment and approximate those expected if the inclusions were under hydrostatic stress. The clustering of measured inclusion strains near isotropic conditions can be attributed to post-entrapment recovery of the deviatoric components that should be present if the behavior of the host-inclusion system was merely elastic and retained a stress and strain state that reflected only the original conditions of entrapment (green ellipses in Fig. 6). In this regard, the other process that can explain the deviations of our results from the numerical predictions is a post-entrapment plastic relaxation of the host-inclusion system (e.g., Carstens 1971).

As described above, the peak metamorphic conditions at $730-750{ }^{\circ} \mathrm{C}$ and $\sim 4 \mathrm{GPa}$ are followed by a large $P$ drop and slight cooling to about $0.5 \mathrm{GPa}$ and $600-650{ }^{\circ} \mathrm{C}$ within a time of about $3 \mathrm{Ma}$. The results of Zhong et al. (2020) suggest that partial or complete plastic relaxation of inclusion stresses can occur by viscous creep in the garnet for $T$ above $650{ }^{\circ} \mathrm{C}$ within a range of time of $1 \mathrm{Ma}$. At lower temperatures, and certainly below $600{ }^{\circ} \mathrm{C}$, the rate of viscous creep becomes so slow as to have negligible effects on inclusion pressures. Therefore, plastic relaxation of the host-inclusion system during exhumation to about $0.5 \mathrm{GPa}$ and $600-650{ }^{\circ} \mathrm{C}$ would explain both the higher inclusion residual pressures (Fig. 5) and the tendency of all of our measured inclusions to exhibit strains and stresses that are closer to isotropic than expected for purely elastic behavior of the host-inclusion system (Fig. 6). In addition, zircon inclusions entrapped within some small pyrope garnet neoblasts $(<2 \mathrm{~mm}$ in size $)$ in the $\mathrm{SiO}_{2}$-rich whiteschists present similar features in terms of inclusion residual pressures and independent strain components (Supplementary materials). This is evidence in favor of the plastic-relaxation hypothesis. However, it is still difficult to understand why some $P_{\text {inc }}$ values are significantly 
higher than $0.6 \mathrm{GPa}$, and why some zircon inclusions in the rims of the garnet megablasts retain the inclusion pressures (but not the strain state) indicative of original entrapment on the prograde path (Fig. 5b).

Previous studies using zircon-in-garnet host-inclusion thermobarometry, from higher-temperature geological settings (e.g., Zhong et al. 2019; Gilio et al. 2020b), reported good agreement between $P-T$ conditions obtained by both zircon-in garnet inclusion and chemically based thermobarometric estimates. At this stage, it is not clear whether this agreement is due to the coincidence that the $P-T$ paths of these rocks approximately follow an isomeke during exhumation (i.e., Zhong et al. 2019) or whether there are still unknown factors that can influence the elastic behavior of the garnet-zircon couple. Further studies are required to better understand these issues.

\section{Conclusions}

The reliability of chemical and elastic thermobarometry has been assessed in a detailed study from the well-known DoraMaira UHP unit. Three garnet megablasts have been investigated in detail by combining major and trace element zoning of garnet and $\mathrm{Zr}$ trace element content in rutile inclusions to constrain the metamorphic conditions of garnet growth and, consequently, inclusion entrapment. Pseudosection modelling of garnet isopleths and Zr-in-rutile-inclusion thermometry suggest garnet formation at about 3-3.5 GPa and $675-720{ }^{\circ} \mathrm{C}$. On the other hand, the elastic method returns zircon entrapment conditions within garnet at inconsistent $P$ and $T$ if the $\mathrm{Zr}$-in-rutile thermometer or the garnet isopleths are combined with the zircon-in-garnet isomekes. In addition, the analyses of the residual strain components of zircon inclusions indicates, for most of them, an approximately isotropic strain state at room conditions that disagrees with the prediction of deviatoric strain expected from numerical models if the entrapment occurred at the conditions inferred from phase equilibria modelling.

The process that best explains our results is a plastic relaxation of the host garnet via dislocation creep (e.g., Zhong et al. 2020) that appears to operate in pyrope-rich garnets down to temperatures of about $600{ }^{\circ} \mathrm{C}$. This interpretation of our data suggests that plastic relaxation in the garnet immediately adjacent to each inclusion is much faster than grain-scale chemical homogenization due to intra-crystalline diffusion, which is not expected to occur at such $T$ conditions and similar timescales (Caddick et al. 2010). As a consequence, zircon-in-garnet thermo-barometry might be more successful for lower temperature metamorphism, where viscous relaxation is negligible and $P-T$ estimation by classic equilibrium thermodynamics can be hampered by incomplete chemical equilibration at the rock scale (Lanari and Hermann 2021). Therefore, because of their complementary nature, the combination of chemical and elastic based thermobarometric estimates is a valuable tool to better characterize and gain detailed information from complex metamorphic paths covering a large evolution- $T$ range where both plastic flow (at high $T$ ) and sluggish chemical diffusion (at low $T$ ) can be expected.

Supplementary Information The online version contains supplementary material available at https://doi.org/10.1007/s00410-021-01793-6.

Acknowledgements This work was financially supported by the European Research Council (ERC) under the European Union's Horizon 2020 research and innovation program Grant Agreements 714936 to M. Alvaro and by the Italian MIUR Progetto di Ricerca di Interesse Nazionale (PRIN) No. 2017ZE49E7 to M. Scambelluri. We really appreciate the comments and suggestions from C. Chopin, S. Schmalholz and an anonymous reviewer that significantly improved the quality of this manuscript. O. Muntener is acknowledged for editorial handling. Special thanks go to D. Rubatto (University of Bern) and the TRUEDEPTHS group for helpful discussion.

Funding Open access funding provided by Università degli Studi di Genova within the CRUI-CARE Agreement.

Open Access This article is licensed under a Creative Commons Attribution 4.0 International License, which permits use, sharing, adaptation, distribution and reproduction in any medium or format, as long as you give appropriate credit to the original author(s) and the source, provide a link to the Creative Commons licence, and indicate if changes were made. The images or other third party material in this article are included in the article's Creative Commons licence, unless indicated otherwise in a credit line to the material. If material is not included in the article's Creative Commons licence and your intended use is not permitted by statutory regulation or exceeds the permitted use, you will need to obtain permission directly from the copyright holder. To view a copy of this licence, visit http://creativecommons.org/licenses/by/4.0/.

\section{References}

Alvaro M, Mazzucchelli ML, Angel RJ, Murri M, Campomenosi N, Scambelluri M, Nestola F, Korsakov A, Tomilenko AA, Marone F, Morana M (2020) Fossil subduction recorded by quartz from the coesite stability field. Geology 48(1):24-28

Angel RJ, Nimis P, Mazzucchelli ML, Alvaro M, Nestola F (2015) How large are departures from lithostatic pressure? Constraints from host-inclusion elasticity. J Metamorph Geol 33(8):801-813

Angel RJ, Murri M, Mihailova BD, Alvaro M (2018) Stress, strain and Raman shifts. Z Kristallogr. https://doi.org/10.1515/ zkri-2018-2112

Binvignat FAP, Malcherek T, Angel RJ, Paulmann C, Schlüter J, Mihailova B (2018) Radiation-damaged zircon under high pressures. Phys Chem Miner 45(10):981-993

Caddick MJ, Konopásek J, Thompson AB (2010) Preservation of garnet growth zoning and the duration of prograde metamorphism. $\mathrm{J}$ Petrol 51(11):2327-2347

Campomenosi N, Mazzucchelli ML, Mihailova B, Scambelluri M, Angel RJ, Nestola F, Reali A, Alvaro M (2018) How geometry and anisotropy affect residual strain in host-inclusion system: coupling experimental and numerical approaches. Am Miner 103:2032-2035 
Campomenosi N, Mazzucchelli ML, Mihailova BD, Angel RJ, Alvaro M (2020a) Using polarized Raman spectroscopy to study the stress gradient in mineral systems with anomalous birefringence. Contrib Mineral Petrol 175(2):1-16

Campomenosi N, Rubatto D, Hermann J, Mihailova B, Scambelluri M, Alvaro M (2020b) Establishing a protocol for the selection of zircon inclusions in garnet for Raman thermobarometry. American Mineral J Earth Planetary Mate 105(7):992-1001. https://doi.org/ 10.2138/am-2020-7246

Carstens H (1971) Plastic stress relaxation around solid inclusions in pyrope. Contrib Mineral Petrol 32(4):289-294

Castelli D, Rolfo F, Groppo C, Compagnoni R (2007) Impure marbles from the UHP Brossasco-Isasca unit (Dora-Maira Massif, Western Alps): evidence for Alpine equilibration in the diamond stability field and evaluation of the $\mathrm{X}\left(\mathrm{CO}_{2}\right)$ fluid evolution. J Metamorph Geol 25(6):587-603

Chopin C (1984) Coesite and pure pyrope in high-grade blueschists of the Western Alps: a first record and some consequences. Contrib Mineral Petrol 86(2):107-118

Chopin C, Henry C, Michard A (1991) Geology and petrology of the coesite-bearing terrain, Dora Maira Massif, Western Alps. Eur J Mineral 3(2):263-291

Coggon R, Holland TJB (2002) Mixing properties of phengitic micas and revised garnet-phengite thermobarometers. J Metamorph Geol 20(7):683-696

Compagnoni R, Hirajima T (2001) Superzoned garnets in the coesitebearing Brossasco-Isasca unit, Dora-Maira Massif, Western Alps, and the origin of the whiteschists. Lithos 57(4):219-236

Compagnoni R, Rolfo F (2003) Ultrahigh-pressure units in the Western Alps. In: Carswell DA, Compagnoni R, Rolfo F (eds) Ultrahighpressure metamorphism. EMU notes in mineralogy, vol 5. Eötvös University Press, Budapest, pp 13-49

Compagnoni R, Hirajima T, Chopin C (1995) Ultra-high-pressure metamorphic rocks in the Western Alps. In: Coleman R, Wang X (eds) Ultrahigh pressure metamorphism. Cambridge University Press, pp 206-243

Connolly JAD (2005) Computation of phase equilibria by linear programming: a tool for geodynamic modeling and its application to subduction zone decarbonation. Earth Planet Sci Lett 236(1-2):524-541

Connolly JAD (2009) The geodynamic equation of state: what and how. Geochemistry, geophysics, geosystems, vol 10. AGU Publications

Enami M, Nishiyama T, Mouri T (2007) Laser Raman microspectrometry of metamorphic quartz: a simple method for comparison of metamorphic pressures. Am Miner 92:1303-1315

Fan D, Lu C, Xu J, Yan B, Yang B, Chen J (2017) Effects of water on PVT equation of state of pyrope. Phys Earth Planet Inter 267:9-18

Ferrando S, Frezzotti ML, Petrelli M, Compagnoni R (2009) Metasomatism of continental crust during subduction: the UHP whiteschists from the southern Dora-Maira Massif (Italian Western Alps). J Metamorph Geol 27(9):739-756

Ferrero S, Angel RJ (2018) Micropetrology: are inclusions grains of truth? J Petrol 59(9):1671-1700

Gauthiez-Putallaz L, Rubatto D, Hermann J (2016) Dating prograde fluid pulses during subduction by in situ $\mathrm{U}-\mathrm{Pb}$ and oxygen isotope analysis. Contrib Mineral Petrol 171(2):15

Gebauer DHPS, Schertl HP, Brix M, Schreyer W (1997) 35 Ma old ultrahigh-pressure metamorphism and evidence for very rapid exhumation in the Dora Maira Massif, Western Alps. Lithos 41(1-3):5-24

Gilio M, Angel JR, Alvaro M (2020a) Elastic geobarometry: how to work with residual inclusion strains and pressures. Am Mineral (In press)
Gilio M, Alvaro M, Angel R, Scambelluri M (2020b) Elastic geothermobarometry on multiple inclusions in a single host. In EGU General Assembly Conference Abstracts (p. 20670)

Groppo C, Ferrando S, Gilio M, Botta S, Nosenzo F, Balestro G, Rolfo F et al (2019) What's in the sandwich? New P-T constraints for the (U)HP nappe stack of southern Dora-Maira Massif (Western Alps). Eur J Mineral 31(4):665-683

Hellstrom J, Paton C, Woodhead J, Hergt J (2008) Iolite: software for spatially resolved LA-(quad and MC) ICPMS analysis, short course series, vol 40. Mineralogical Association of Canada, pp 343-348

Henry C, Michard A, Chopin C (1993) Geometry and structural evolution of ultra-high-pressure and high-pressure rocks from the Dora-Maira Massif, Western Alps, Italy. J Struct Geol 15:965-965

Hermann J (2003) Experimental evidence for diamond-facies metamorphism in the Dora-Maira Massif. Lithos 70(3-4):163-182

Hermann J, Spandler CJ (2008) Sediment melts at sub-arc depths: an experimental study. J Petrol 49(4):717-740

Holland TJB, Powell R (2011) An improved and extended internally consistent thermodynamic dataset for phases of petrological interest, involving a new equation of state for solids. J Metamorph Geol 29(3):333-383

Howell D, Wood IG, Dobson DP, Jones AP, Nasdala L, Harris JW (2010) Quantifying strain birefringence halos around inclusions in diamond. Contrib Mineral Petrol 160(5):705-717

Kohn MJ (2014) “Thermoba-Raman-try": calibration of spectroscopic barometers and thermometers for mineral inclusions. Earth Planetary Sci Lett 388:187-196

Kohn MJ, Corrie SL, Markley C (2015) The fall and rise of metamorphic zircon. Am Miner 100(4):897-908

Lanari P, Hermann J (2021) Iterative thermodynamic modelling — part 2: tracing equilibrium relationships between minerals in metamorphic rocks. J Metamorph Geol. https://doi.org/10.1111/jmg. 12575 (In press)

Malusà MG, Faccenna C, Baldwin SL, Fitzgerald PG, Rossetti F, Balestrieri ML, Danisik M, Ellero A, Ottria G, Piromallo C (2015) Contrasting styles of (U)HP rock exhumation along the Cenozoic Adria-Europe plate boundary (Western Alps, Calabria, Corsica). Geochem Geophys Geosyst 16(6):1786-1824

Mazzucchelli ML, Burnley P, Angel RJ, Morganti S, Domeneghetti MC, Nestola F, Alvaro M (2018) Elastic geothermobarometry: corrections for the geometry of the host-inclusion system. Geology 46(3):231-234

Mazzucchelli ML, Reali A, Morganti S, Angel RJ, Alvaro M (2019) Elastic geobarometry for anisotropic inclusions in cubic hosts. Lithos 350-351:105218

Mazzucchelli ML, Angel RJ, Alvaro M (2021) EntraPT: an online application for elastic geothermobarometry. American Mineralogist. https://doi.org/10.2138/am-2021-7693CCBYNCND

Murri M, Mazzucchelli ML, Campomenosi N, Korsakov AV, Prencipe M, Mihailova BD, Scambelluri M, Angel RJ, Alvaro M (2018) Raman elastic geobarometry for anisotropic mineral inclusions. Am Miner 103(11):1869-1872

Musiyachenko KA, Murri M, Prencipe M, Angel RJ, Alvaro M (2020) A Grüneisen tensor for rutile and its application to host-inclusion systems. American Mineralogist. https://doi.org/10.2138/ am-2021-7618

Nasdala L, Brenker FE, Glinnemann J, Hofmeister W, Gasparik T, Harris JW, Stachel T, Reese I (2003) Spectroscopic 2D-tomography: residual pressure and strain around mineral inclusions in diamonds. Eur J Mineral 15(6):931-935

Nimis P, Alvaro M, Nestola F, Angel RJ, Marquardt K, Rustioni G, Harris JW, Marone F (2016) First evidence of hydrous silicic fluid films around solid inclusions in gem-quality diamonds. Lithos 260:384-389 
Osborne ZR, Thomas JB, Nachlas WO, Baldwin SL, Holycross ME, Spear FS, Watson EB (2019) An experimentally calibrated thermobarometric solubility model for titanium in coesite (TitaniC). Contributions Mineral Petrol 174(4):1-13

Özkan H, Cartz L, Jamieson JC (1974) Elastic constants of nonmetamict zirconium silicate. J Appl Phys 45(2):556-562

Paton C, Hellstrom J, Paul B, Woodhead J, Hergt J (2011) Iolite: freeware for the visualisation and processing of mass spectrometric data. J Anal At Spectrom 26:2508-2518

Rosenfeld JL, Chase AB (1961) Pressure and temperature of crystallization from elastic effects around solid inclusions in minerals? Am J Sci 259(7):519-541

Rubatto D, Hermann J (2001) Exhumation as fast as subduction? Geology 29(1):3-6

Schenker FL, Schmalholz SM, Moulas E, Pleuger J, Baumgartner LP, Podladchikov Y, Vrijmoed J, Buchs N, Müntener O (2015) Current challenges for explaining (ultra) high-pressure tectonism in the Pennine domain of the Central and Western Alps. J Metamorph Geol 33(8):869-886

Schertl HP, Schreyer W (2008) Geochemistry of coesite-bearing "pyrope quartzite" and related rocks from the Dora-Maira Massif, Western Alps. Eur J Mineral 20(5):791-809

Schertl HP, Schreyer W, Chopin C (1991) The pyrope-coesite rocks and their country rocks at Parigi, Dora Maira Massif, Western Alps: detailed petrography, mineral chemistry and PT-path. Contrib Mineral Petrol 108(1-2):1-21

Schreyer W (1988) Experimental studies on metamorphism of crustal rocks under mantle pressures. Mineral Mag 52(364):1-26

Sharp ZD, Essene EJ, Hunziker JC (1993) Stable isotope geochemistry and phase equilibria of coesite-bearing whiteschists, Dora Maira Massif, Western Alps. Contrib Mineral Petrol 114(1):1-12

Simon G, Chopin C (2001) Enstatite-sapphirine crack-related assemblages in ultrahigh-pressure pyrope megablasts, Dora-Maira massif, Western Alps. Contrib Mineral Petrol 140(4):422-440

Simon G, Chopin C, Schenk V (1997) Near-end-member magnesiochloritoid in prograde-zoned pyrope, Dora-Maira Massif, Western Alps. Lithos 41(1-3):37-57

Spear FS, Peacock SM (1989) Metamorphic pressure-temperature-time paths, vol 7. American Geophysical Union
Stangarone C, Angel RJ, Prencipe M, Campomenosi N, Mihailova B, Alvaro M (2019) Measurement of strains in zircon inclusions by Raman spectroscopy. Eur J Mineral 31(4):685-694

Tilton GR, Schreyer W, Schertl HP (1989) Pb-Sr-Nd isotopic behavior of deeply subducted crustal rocks from the Dora Maira Massif, Western Alps, Italy. Geochimica et Cosmochimica Acta 53(6):1391-1400

Tilton GR, Schreyer W, Schertl HP (1991) Pb-Sr-Nd isotopic behavior of deeply subducted crustal rocks from the Dora Maira Massif, Western Alps, Italy-II: what is the age of the ultrahigh-pressure metamorphism?. Contributions Mineral Petrol 108(1):22-33

Tomkins HS, Powell R, Ellis DJ (2007) The pressure dependence of the zirconium-in-rutile thermometer. J Metamorph Geol 25(6):703-713

van der Molen I, van Roermund HLM (1986) The pressure path of solid inclusions in minerals: the retention of coesite inclusions during uplift. Lithos 19:317-324

Woodhead JD, Hellstrom J, Hergt JM, Greig A, Maas R (2007) Isotopic and elemental imaging of geological materials by laser ablation inductively coupled plasma-mass spectrometry. Geostand Geoanal Res 31:331-343

Xu L, Mei S, Dixon N, Jin Z, Suzuki AM, Kohlstedt DL (2013) Effect of water on rheological properties of garnet at high temperatures and pressures. Earth Planet Sci Lett 379:158-165

Zhang Y (1998) Mechanical and phase equilibria in inclusion-host systems. Earth Planet Sci Lett 157(3-4):209-222

Zhong X, Andersen NH, Dabrowski M, Jamtveit B (2019) Zircon and quartz inclusions in garnet used for complementary Raman thermobarometry: application to the Holsnøy eclogite, Bergen Arcs, Western Norway. Contrib Mineral Petrol 174(6):50

Zhong X, Moulas E, Tajčmanová L (2020) Post-entrapment modification of residual inclusion pressure and its implications for Raman elastic thermobarometry. Solid Earth 11(1):223-240

Publisher's Note Springer Nature remains neutral with regard to jurisdictional claims in published maps and institutional affiliations. 